\title{
Editorial
}

\section{New Research and Trends in Higher Education}

\author{
Maria José Sousa ${ }^{1, *(\mathbb{D}}$, Fátima Suleman ${ }^{2} \mathbb{D}$, Pere Mercadé Melé ${ }^{3} \mathbb{D}$ and Jesús Molina Gómez ${ }^{4}(\mathbb{D}$ \\ 1 Department of Political Science and Public Policies, ISCTE-Instituto Universitário de Lisboa, \\ 1649-026 Lisboa, Portugal \\ 2 Department of Political Economy, ISCTE-Instituto Universitário de Lisboa, 1649-026 Lisboa, Portugal; \\ fatima.suleman@iscte-iul.pt \\ 3 Department of Statistics and Econometrics, University of Malaga, Campus el Ejido s/n, 29071 Malaga, Spain; \\ pmercade@uma.es \\ 4 Department of Economics and Business, University of Malaga, Campus el Ejido s/n, 29071 Malaga, Spain; \\ jmolinag@uma.es \\ * Correspondence: maria.jose.sousa@iscte-iul.pt
}

check for updates

Citation: Sousa, M.J.; Suleman, F.; Melé, P.M.; Gómez, J.M. New Research and Trends in Higher Education. Educ. Sci. 2021, 11, 456. https://doi.org/10.3390/ educsci11090456

Received: 16 August 2021

Accepted: 17 August 2021

Published: 24 August 2021

Publisher's Note: MDPI stays neutral with regard to jurisdictional claims in published maps and institutional affiliations.

Copyright: (C) 2021 by the authors. Licensee MDPI, Basel, Switzerland. This article is an open access article distributed under the terms and conditions of the Creative Commons Attribution (CC BY) license (https:/ / creativecommons.org/licenses/by/ $4.0 /)$.

\section{Introduction}

New methodologies, contexts, and technologies are generating a lot of interest in the field of higher education, and this Special Issue intends to address the current research and trends in all dimensions of higher education. It will serve as a global focal point for the examination and reporting of a wide range of issues affecting higher education learning processes: innovations in learning, new pedagogical methods and new learning contexts. The Special Issue includes original research contributions, such as research papers, case studies and demonstrations with original scientific results, methodological aspects, concepts and educational technologies on the following topics: (a) Technological Developments in Higher Education: mobile technology, virtual environments, augmented reality, automation and robotics and other tools for universal learning, focusing on issues that are not addressed by existing research. (b) Digital Higher Education: mobile learning, eLearning, Game-based Learning, social media in education, new learning models and technologies and wearable technologies for education. (c) Case Studies in Higher Education: empirical studies in higher education regarding digital technologies, new methodologies, new evaluation techniques and tools, perceptions of learning processes efficiency and digital learning best practices.

\section{New Research and Trends in Higher Education Special Issue Overview}

The Special Issue includes 26 articles (Table 1) that discusses the social responsibility among higher education students; the use of storytelling towards becoming more autoethnographic in academia; the Spanish adaptation of a motivational climate scale with university students; the emotional and spiritual intelligence of future leaders: challenges for education; how to measure the degree of academic satisfaction; transversal competences in engineering degrees: integrating content and foreign language teaching; theoretical learning analytics frameworks for stem education virtual reality applications; the interaction between higher education institutions and professional bodies in the context of digital transformation; student-centered and ICT-enabled learning models in veterinarian programs: what changed with COVID-19; upgrading a learning context: evaluation of Sentra's educational project; the unbearable lightness of academic fraud: Portuguese higher education students' perceptions; distance learning perceptions from higher education students- the case of Portugal; a study of the emotional intelligence and personality traits of university finance students; student burnout: a case study about a Portuguese public university; mechatronics: experiential learning and the stimulation of thinking skills; higher education and employability skills: barriers and facilitators of employer engagement at local level; teaching sentiment in emergency online learning-a conceptual model; development and psychometric properties of a scale to measure resilience 
among Portuguese university students: resilience scale-10; using peer review for student performance enhancement: experiences in a multidisciplinary higher education setting; cyber-archaeometry: novel research and learning subject overview; does postsecondary education attainment matter in community service engagement? evidence from across 18 OECD countries; the soft skills of special education teachers: evidence from the literature; learner-centred learning tasks in higher education: a study on perception among students; STEM faculty instructional data-use practices: informing teaching practice and students' reflection on students' learning; drawing skills of candidates for architectural studies vs. learning outcomes of graduates: comparative research based on the example of the faculty of architecture; and life science students' understanding of the role of plants in the ecosystem-a concept network analysis.

Table 1. Articles in the Special Issue.

\begin{tabular}{|c|c|c|}
\hline Author & Title & Keywords \\
\hline [1] Au-Yong-Oliveira, Manuel & $\begin{array}{c}\text { Using Reflexive, Introspective } \\
\text { and Storytelling Tools: } \\
\text { Towards Becoming More } \\
\text { Autoethnographic in } \\
\text { Academia }\end{array}$ & $\begin{array}{l}\text { Patagonia; trekking; nature; } \\
\text { goodness of humankind; } \\
\text { culture; individuality; } \\
\text { reflexivity; qualitative } \\
\text { research }\end{array}$ \\
\hline [2] Berei, Emese & $\begin{array}{c}\text { The Social Responsibility } \\
\text { among Higher Education } \\
\text { Students }\end{array}$ & $\begin{array}{l}\text { higher education students; } \\
\text { social responsibility; private } \\
\text { and state institutions; romania }\end{array}$ \\
\hline $\begin{array}{l}\text { [3] Granero-Gallegos, Antonio; } \\
\text { Carrasco-Poyatos, María }\end{array}$ & $\begin{array}{l}\text { Spanish Adaptation of } \\
\text { Motivational Climate in } \\
\text { Education Scale with } \\
\text { University Students }\end{array}$ & $\begin{array}{l}\text { validation; mastery; task; } \\
\text { performance; ego }\end{array}$ \\
\hline [4] Samul, Joanna & $\begin{array}{l}\text { Emotional and Spiritual } \\
\text { Intelligence of Future Leaders: } \\
\text { Challenges for Education }\end{array}$ & $\begin{array}{l}\text { spiritual intelligence; } \\
\text { emotional intelligence; } \\
\text { leadership; education }\end{array}$ \\
\hline $\begin{array}{c}\text { [5] Walter, Cicero; Miranda } \\
\text { Veloso, Cláudia; } \\
\text { Au-Yong-Oliveira, Manuel }\end{array}$ & $\begin{array}{c}\text { Measuring the Degree of } \\
\text { Academic Satisfaction: The } \\
\text { Case of a Brazilian National } \\
\text { Institute }\end{array}$ & $\begin{array}{l}\text { satisfaction; educational } \\
\text { management; average } \\
\text { satisfaction index; IFPI; Brazil }\end{array}$ \\
\hline $\begin{array}{c}\text { [6] Oksana, Polyakova; } \\
\text { Galstyan-Sargsyan, Ruzana; } \\
\text { López-Jiménez, P.; } \\
\text { Pérez-Sánchez, Modesto }\end{array}$ & $\begin{array}{l}\text { Transversal Competences in } \\
\text { Engineering Degrees: } \\
\text { Integrating Content and } \\
\text { Foreign Language Teaching }\end{array}$ & $\begin{array}{c}\text { transversal competences; } \\
\text { engineering students; higher } \\
\text { education }\end{array}$ \\
\hline $\begin{array}{l}\text { [7] Christopoulos, Athanasios; } \\
\text { Pellas, Nikolaos; Laakso, } \\
\text { Mikko-Jussi }\end{array}$ & $\begin{array}{l}\text { A Learning Analytics } \\
\text { Theoretical Framework for } \\
\text { STEM Education Virtual } \\
\text { Reality Applications }\end{array}$ & $\begin{array}{l}\text { virtual reality; learning } \\
\text { analytics; STEM education; } \\
\text { instructional design }\end{array}$ \\
\hline $\begin{array}{l}\text { [8] Bonzanini, Osmar; Silva, } \\
\text { Amélia; Cokins, Gary; } \\
\text { Gonçalves, Maria }\end{array}$ & $\begin{array}{l}\text { The Interaction between } \\
\text { Higher Education Institutions } \\
\text { and Professional Bodies in the } \\
\text { Context of Digital } \\
\text { Transformation: The Case of } \\
\text { Brazilian Accountants }\end{array}$ & $\begin{array}{l}\text { accountant; professions; } \\
\text { digital; professional bodies; } \\
\text { higher education institutions }\end{array}$ \\
\hline $\begin{array}{c}\text { [9] Gonçalves, Eva; Capucha, } \\
\text { Luís }\end{array}$ & $\begin{array}{c}\text { Student-Centered and } \\
\text { ICT-Enabled Learning Models } \\
\text { in Veterinarian Programs: } \\
\text { What Changed with } \\
\text { COVID-19? }\end{array}$ & $\begin{array}{l}\text { learning models; use of icts; } \\
\text { higher education; veterinarian } \\
\text { education; COVID-19 }\end{array}$ \\
\hline
\end{tabular}


Table 1. Cont.

\begin{tabular}{|c|c|c|}
\hline Author & Title & Keywords \\
\hline $\begin{array}{l}\text { [10] Querido, Lara; Capucha, } \\
\text { Luís; Nunes, Nuno }\end{array}$ & $\begin{array}{l}\text { Upgrading a Learning } \\
\text { Context: Evaluation of } \\
\text { Sintra's Educational Project }\end{array}$ & $\begin{array}{l}\text { learning contexts; operational } \\
\text { assistants; training; } \\
\text { evaluation; higher education; } \\
\text { educational public policies }\end{array}$ \\
\hline $\begin{array}{l}\text { [11] Ramos, Rosária; } \\
\text { Gonçalves, Joaquim; } \\
\text { Gonçalves, Sónia }\end{array}$ & $\begin{array}{c}\text { The Unbearable Lightness of } \\
\text { Academic Fraud: Portuguese } \\
\text { Higher Education Students' } \\
\text { Perceptions }\end{array}$ & $\begin{array}{l}\text { academic fraud; academic } \\
\text { integrity; higher education; } \\
\text { perceptions; students }\end{array}$ \\
\hline $\begin{array}{l}\text { [12] Gonçalves, Sónia; Sousa, } \\
\text { Maria; Pereira, Fernanda }\end{array}$ & $\begin{array}{c}\text { Distance Learning Perceptions } \\
\text { from Higher Education } \\
\text { Students-The Case of } \\
\text { Portugal }\end{array}$ & $\begin{array}{l}\text { distance learning; higher } \\
\text { education; online learning; } \\
\text { digital pedagogies; students }\end{array}$ \\
\hline $\begin{array}{l}\text { [13] Rosales-Pérez, Ana; } \\
\text { Fernández-Gámez, Manuel; } \\
\text { Torroba-Díaz, Macarena; } \\
\text { Molina-Gómez, Jesús }\end{array}$ & $\begin{array}{c}\text { A Study of the Emotional } \\
\text { Intelligence and Personality } \\
\text { Traits of University Finance } \\
\text { Students }\end{array}$ & $\begin{array}{c}\text { financial education; emotional } \\
\text { intelligence; personality traits; } \\
\text { financial behavior; university } \\
\text { students }\end{array}$ \\
\hline $\begin{array}{c}\text { [14] Salgado, Sofia; } \\
\text { Au-Yong-Oliveira, Manuel }\end{array}$ & $\begin{array}{c}\text { Student Burnout: A Case } \\
\text { Study about a Portuguese } \\
\text { Public University }\end{array}$ & $\begin{array}{l}\text { academic burnout; stress; } \\
\text { higher education; quantitative } \\
\text { research; coping strategies; } \\
\text { medication }\end{array}$ \\
\hline $\begin{array}{l}\text { [15] Habib, Maki; Nagata, } \\
\text { Fusaomi; Watanabe, Keigo }\end{array}$ & $\begin{array}{l}\text { Mechatronics: Experiential } \\
\text { Learning and the Stimulation } \\
\text { of Thinking Skills }\end{array}$ & $\begin{array}{l}\text { mechatronics; experiential } \\
\text { learning; creative thinking; } \\
\text { critical thinking; robotics; } \\
\text { thinking skills; subsumption } \\
\text { architecture; mobile robot; } \\
\text { educational system; } \\
\text { project-based learning }\end{array}$ \\
\hline $\begin{array}{l}\text { [16] Suleman, Fátima; Videira, } \\
\text { Pedro; Araújo, Emília }\end{array}$ & $\begin{array}{l}\text { Higher Education and } \\
\text { Employability Skills: Barriers } \\
\text { and Facilitators of Employer } \\
\text { Engagement at Local Level }\end{array}$ & $\begin{array}{l}\text { higher education; employers' } \\
\text { engagement; employability; } \\
\text { multi-stakeholder partnership }\end{array}$ \\
\hline $\begin{array}{l}\text { [17] Martinho, Domingos; } \\
\text { Sobreiro, Pedro; Vardasca, } \\
\text { Ricardo }\end{array}$ & $\begin{array}{l}\text { Teaching Sentiment in } \\
\text { Emergency Online } \\
\text { Learning-A Conceptual } \\
\text { Model }\end{array}$ & $\begin{array}{l}\text { COVID-19; emergency online } \\
\text { learning; emergency online } \\
\text { teaching; higher education; } \\
\text { lecturers; online learning; } \\
\text { portugal; sentiment analysis }\end{array}$ \\
\hline $\begin{array}{l}\text { [18] Jardim, Jacinto; Pereira, } \\
\text { Anabela; Bártolo, Ana }\end{array}$ & $\begin{array}{l}\text { Development and } \\
\text { Psychometric Properties of a } \\
\text { Scale to Measure Resilience } \\
\text { among Portuguese University } \\
\text { Students: Resilience Scale-10 }\end{array}$ & $\begin{array}{l}\text { resilience; validity; higher } \\
\text { education; resilience scale-10 }\end{array}$ \\
\hline $\begin{array}{l}\text { [19] Serrano-Aguilera, Juan; } \\
\text { Tocino, Alicia; Fortes, Sergio; } \\
\text { Martín, Cristian; } \\
\text { Mercadé-Melé, Pere; } \\
\text { Moreno-Sáez, Rafael; Muñoz, } \\
\text { Antonio; Palomo-Hierro, Sara; } \\
\text { Torres, Antoni }\end{array}$ & $\begin{array}{l}\text { Using Peer Review for } \\
\text { Student Performance } \\
\text { Enhancement: Experiences in } \\
\text { a Multidisciplinary Higher } \\
\text { Education Setting }\end{array}$ & $\begin{array}{l}\text { peer assessment; peer review; } \\
\text { collaborative evaluation; } \\
\text { higher education; rubric }\end{array}$ \\
\hline $\begin{array}{l}\text { [20] Liritzis, Ioannis; } \\
\text { Volonakis, Pantelis }\end{array}$ & $\begin{array}{l}\text { Cyber-Archaeometry: Novel } \\
\text { Research and Learning } \\
\text { Subject Overview }\end{array}$ & $\begin{array}{c}\text { educational; virtual } \\
\text { environment; virtual reality; } \\
\text { gamification; 3d modeling; } \\
\text { cultural heritage; } \\
\text { cyber-archaeology; } \\
\text { microscope }\end{array}$ \\
\hline
\end{tabular}


Table 1. Cont.

\begin{tabular}{|c|c|c|}
\hline Author & Title & Keywords \\
\hline [21] Gong, Hee; Hong, Jung & $\begin{array}{l}\text { Does Postsecondary } \\
\text { Education Attainment Matter } \\
\text { in Community Service } \\
\text { Engagement? Evidence from } \\
\text { Across } 18 \text { OECD Countries }\end{array}$ & $\begin{array}{l}\text { postsecondary education; } \\
\text { higher education; community } \\
\text { service; civic engagement; } \\
\text { educational attainment; } \\
\text { OECD country; hierarchical } \\
\text { linear model (HLM); PIAAC }\end{array}$ \\
\hline $\begin{array}{c}\text { [22] Fernandes, Patrícia; } \\
\text { Jardim, Jacinto; Lopes, Maria }\end{array}$ & $\begin{array}{c}\text { The Soft Skills of Special } \\
\text { Education Teachers: Evidence } \\
\text { from the Literature }\end{array}$ & $\begin{array}{l}\text { soft skills; inclusion; teachers } \\
\text { of special education; teacher } \\
\text { profile; effective } \\
\text { communication }\end{array}$ \\
\hline [23] Li, Junmin & $\begin{array}{l}\text { Learner-Centred Learning } \\
\text { Tasks in Higher Education: A } \\
\text { Study on Perception among } \\
\text { Students }\end{array}$ & $\begin{array}{l}\text { self-directed learning; } \\
\text { learning tasks; student } \\
\text { surveys; university didactics }\end{array}$ \\
\hline $\begin{array}{c}\text { [24] Lenhart, Cindy; } \\
\text { Bouwma-Gearhart, Jana }\end{array}$ & $\begin{array}{l}\text { STEM Faculty Instructional } \\
\text { Data-Use Practices: Informing } \\
\text { Teaching Practice and } \\
\text { Students' Reflection on } \\
\text { Students' Learning }\end{array}$ & $\begin{array}{c}\text { STEM; undergraduates; } \\
\text { instructional data; teaching } \\
\text { practices; instructional } \\
\text { technology; assessment; } \\
\text { student reflection on learning; } \\
\text { policy }\end{array}$ \\
\hline $\begin{array}{c}\text { [25] Gawlak, Agata; } \\
\text { Pruszewicz-Sipińska, Ewa; } \\
\text { Bonenberg, Wojciech }\end{array}$ & $\begin{array}{l}\text { Drawing Skills of Candidates } \\
\text { for Architectural Studies vs. } \\
\text { Learning Outcomes of } \\
\text { Graduates. Comparative } \\
\text { Research Based on the } \\
\text { Example of The Faculty of } \\
\text { Architecture, Poznan } \\
\text { University of Technology }\end{array}$ & $\begin{array}{c}\text { architectural education; } \\
\text { architectural studies; } \\
\text { admission exam in drawing; } \\
\text { higher education; drawing }\end{array}$ \\
\hline $\begin{array}{l}\text { [26] Södervik, Ilona; } \\
\text { Nousiainen, Maija; Koponen, } \\
\text { Ismo. }\end{array}$ & $\begin{array}{l}\text { First-Year Life Science } \\
\text { Students' Understanding of } \\
\text { the Role of Plants in the } \\
\text { Ecosystem-A Concept } \\
\text { Network Analysis }\end{array}$ & $\begin{array}{l}\text { concept; knowledge } \\
\text { integration; macro-concept; } \\
\text { language of science; network } \\
\text { analysis; photosynthesis; } \\
\text { biology education; science } \\
\text { education; higher education }\end{array}$ \\
\hline
\end{tabular}

To create an overview of the new research and trends in higher education, an analysis of the articles is presented using the VOSViewer software to show the network of the research attributes included in title and abstracts, as well as the co-authorship network.

\subsection{Co-Authorship}

Vosviewer is a program for creating networks and analyzing the strength of associations between variables-in this case, the co-authorships are being analyzed.

Because of the highly interdisciplinary nature of the studies, researchers are coming from different domains, such as education, computer science, management, psychology and others, where complementary advantages could be achieved through cooperation. Creating and analyzing the knowledge maps of the co-authorship network of productive authors can provide valuable information for research centers to develop cooperation groups and for individual researchers to seek cooperation.

In this sense, Figure 1 illustrates the network of the authors of the papers under analysis. 


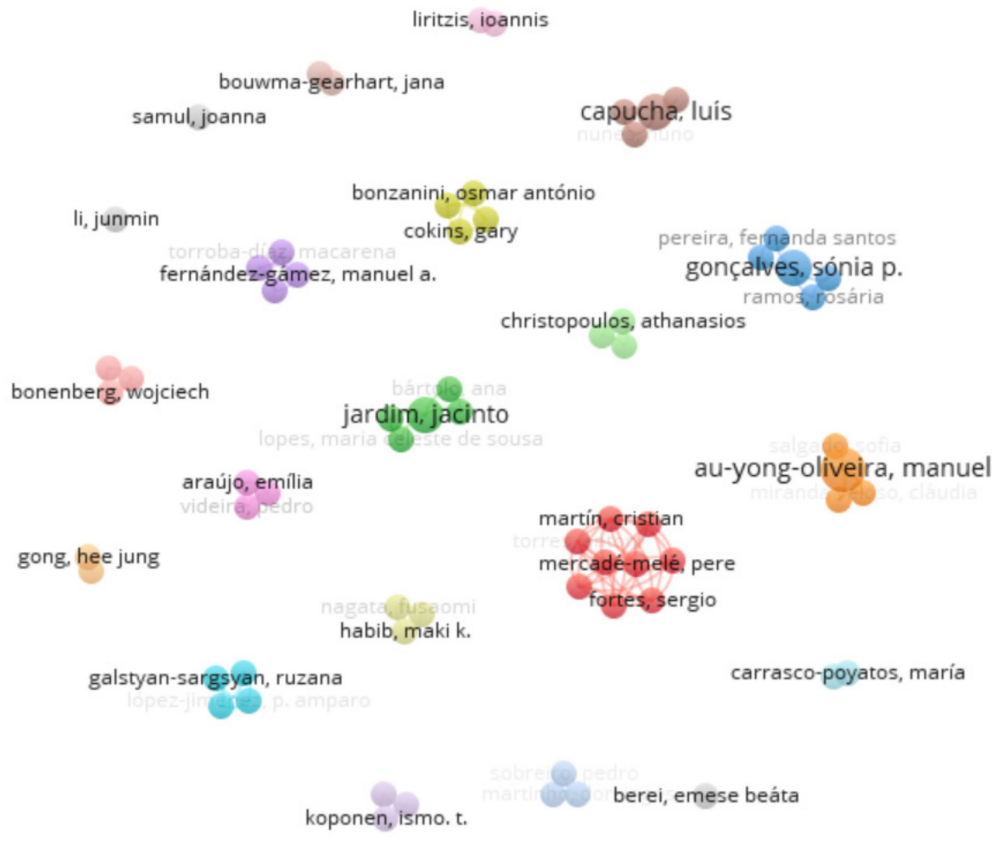

Figure 1. Co-authorship network.

Figure 1 shows the nodes representing the authors, and the node size indicates the number of published articles. The link connecting two nodes represents the cooperative relation between two authors, and the thickness of the link stands for the intensity of cooperation. Overall, the cooperation among productive authors is not close, however, there are several co-authorship groups. Co-authoring publications have critical significance for promoting research innovation and knowledge sharing, as well as improving the quality of research. However, according to the analysis results on main research groups, most productive authors are in fact independent authors (grey nodes in Figure 1), and the scale of such cooperation is nevertheless small and unstable, lacking effective international exchange and cooperation.

\subsection{Keywords}

Regarding the keywords (Figure 2), there is a strong link strength between several keywords, based on equal distance. Higher education is the strongest keyword represented in the network. However, there are several keywords without association, represented in the orbit of the network. These are: higher education students; virtual reality; learning tasks; creative thinking; assessment; emotional intelligence; culture; and effective communication. 


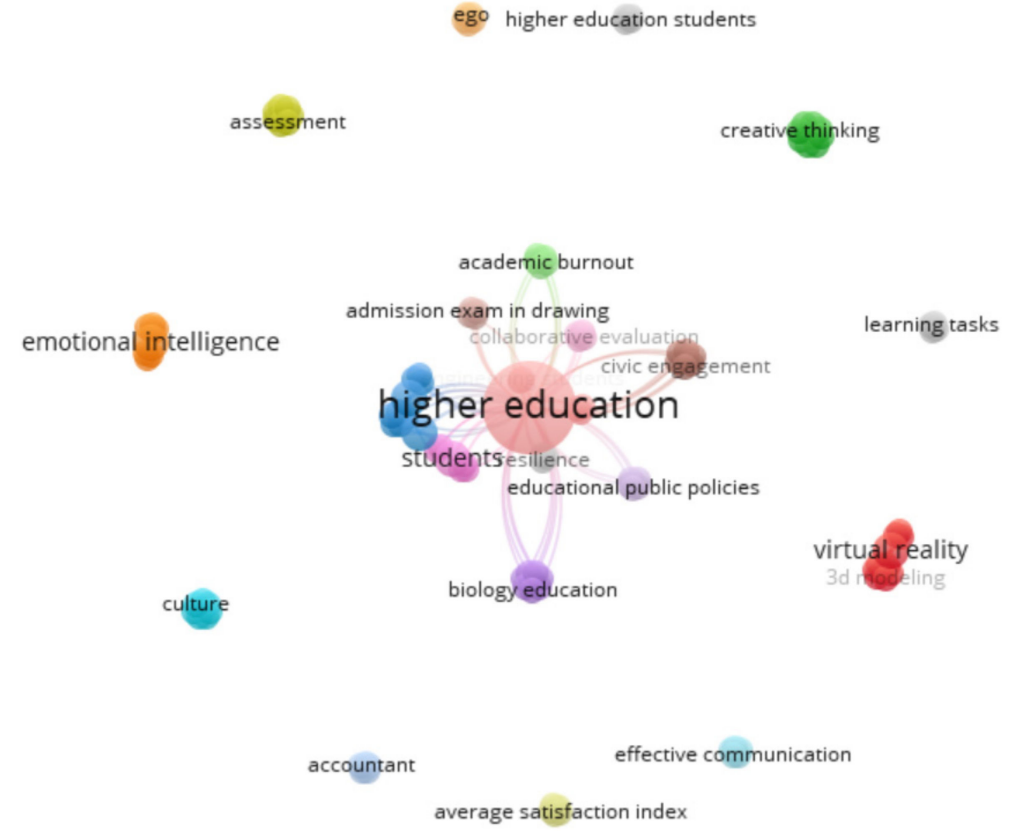

Figure 2. Keyword network.

\subsection{Research Attributes and Expressions in Title and Abstract}

The network regarding research attributes and expressions in title and abstract (Figure 3) is more complex, and represents six clusters. The purple cluster is related to the motivational climate and the university students, the orange cluster is related with tasks and integration, the red cluster is focused on the application and the outcomes of education, the yellow cluster is focused on the learning process and quality, the green cluster is related to impact and attitude in relation to higher education, and the dark blue cluster is related to the faculty, the practice and the COVID-19 context.

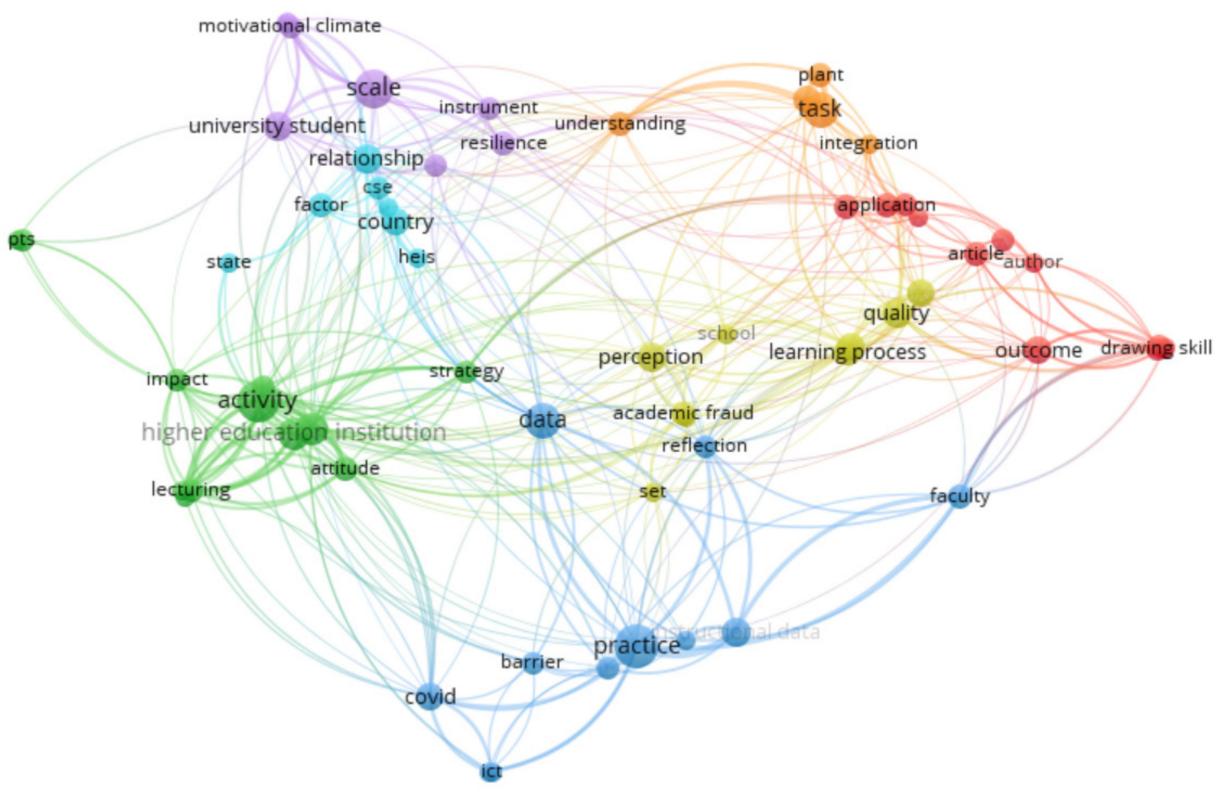

Figure 3. Research attributes and expressions in the title and abstract.

Author Contributions: Conceptualization, M.J.S. and P.M.M.; Methodology, M.J.S. and P.M.M.; Validation, M.J.S., F.S., P.M.M. and J.M.G.; writing—original draft preparation, M.J.S., F.S., P.M.M. 
and J.M.G.; writing-review and editing, M.J.S., F.S., P.M.M. and J.M.G. All authors have read and agreed to the published version of the manuscript.

Funding: This research received no external funding.

Data Availability Statement: Not applicable.

Conflicts of Interest: The authors declare no conflict of interest.

\section{References}

1. Au-Yong-Oliveira, M. Using Reflexive, Introspective and Storytelling Tools: Towards Becoming More Autoethnographic in Academia. Educ. Sci. 2020, 10, 120. [CrossRef]

2. Berei, E.B. The Social Responsibility among Higher Education Students. Educ. Sci. 2020, 10, 66. [CrossRef]

3. Bonzanini, O.A.; Silva, A.; Cokins, G.; Gonçalves, M.J. The Interaction between Higher Education Institutions and Professional Bodies in the Context of Digital Transformation: The Case of Brazilian Accountants. Educ. Sci. 2020, 10, 321. [CrossRef]

4. Christopoulos, A.; Pellas, N.; Laakso, M.-J. A Learning Analytics Theoretical Framework for STEM Education Virtual Reality Applications. Educ. Sci. 2020, 10, 317. [CrossRef]

5. Gonçalves, E.; Capucha, L. Student-Centered and ICT-Enabled Learning Models in Veterinarian Programs: What Changed with COVID-19? Educ. Sci. 2020, 10, 343. [CrossRef]

6. Gonçalves, S.P.; Sousa, M.J.; Pereira, F.S. Distance Learning Perceptions from Higher Education Students-The Case of Portugal. Educ. Sci. 2020, 10, 374. [CrossRef]

7. Granero-Gallegos, A.; Carrasco-Poyatos, M. Spanish Adaptation of Motivational Climate in Education Scale with University Students. Educ. Sci. 2020, 10, 157. [CrossRef]

8. Oksana, P.; Galstyan-Sargsyan, R.; López-Jiménez, P.A.; Pérez-Sánchez, M. Transversal Competences in Engineering Degrees: Integrating Content and Foreign Language Teaching. Educ. Sci. 2020, 10, 296. [CrossRef]

9. Querido, L.; Capucha, L.; Nunes, N. Upgrading a Learning Context: Evaluation of Sintra's Educational Project. Educ. Sci. 2020, 10, 344. [CrossRef]

10. Ramos, R.; Gonçalves, J.; Gonçalves, S.P. The Unbearable Lightness of Academic Fraud: Portuguese Higher Education Students' Perceptions. Educ. Sci. 2020, 10, 351. [CrossRef]

11. Samul, J. Emotional and Spiritual Intelligence of Future Leaders: Challenges for Education. Educ. Sci. 2020, 10, 178. [CrossRef]

12. Walter, C.E.; Veloso, C.M.; Au-Yong-Oliveira, M. Measuring the Degree of Academic Satisfaction: The Case of a Brazilian National Institute. Educ. Sci. 2020, 10, 266. [CrossRef]

13. Da Silva Fernandes, P.R.; Jardim, J.; de Sousa Lopes, M.C. The Soft Skills of Special Education Teachers: Evidence from the Literature. Educ. Sci. 2021, 11, 125. [CrossRef]

14. Gawlak, A.; Pruszewicz-Sipińska, E.; Bonenberg, W. Drawing Skills of Candidates for Architectural Studies vs. Learning Outcomes of Graduates. Comparative Research Based on the Example of The Faculty of Architecture, Poznan University of Technology. Educ. Sci. 2021, 11, 339. [CrossRef]

15. Gong, H.J.; Hong, J.E. Does Postsecondary Education Attainment Matter in Community Service Engagement? Evidence from Across 18 OECD Countries. Educ. Sci. 2021, 11, 96. [CrossRef]

16. Habib, M.K.; Nagata, F.; Watanabe, K. Mechatronics: Experiential Learning and the Stimulation of Thinking Skills. Educ. Sci. 2021, 11, 46. [CrossRef]

17. Jardim, J.; Pereira, A.; Bártolo, A. Development and Psychometric Properties of a Scale to Measure Resilience among Portuguese University Students: Resilience Scale-10. Educ. Sci. 2021, 11, 61. [CrossRef]

18. Lenhart, C.; Bouwma-Gearhart, J. STEM Faculty Instructional Data-Use Practices: Informing Teaching Practice and Students' Reflection on Students' Learning. Educ. Sci. 2021, 11, 291. [CrossRef]

19. Li, J. Learner-Centred Learning Tasks in Higher Education: A Study on Perception among Students. Educ. Sci. 2021, 11, 230. [CrossRef]

20. Liritzis, I.; Volonakis, P. Cyber-Archaeometry: Novel Research and Learning Subject Overview. Educ. Sci. 2021, 11, 86. [CrossRef]

21. Martinho, D.; Sobreiro, P.; Vardasca, R. Teaching Sentiment in Emergency Online Learning-A Conceptual Model. Educ. Sci. 2021, 11, 53. [CrossRef]

22. Rosales-Pérez, A.M.; Fernández-Gámez, M.A.; Torroba-Díaz, M.; Molina-Gómez, J. A Study of the Emotional Intelligence and Personality Traits of University Finance Students. Educ. Sci. 2021, 11, 25. [CrossRef]

23. Salgado, S.; Au-Yong-Oliveira, M. Student Burnout: A Case Study about a Portuguese Public University. Educ. Sci. 2021, 11, 31. [CrossRef]

24. Serrano-Aguilera, J.J.; Tocino, A.; Fortes, S.; Martín, C.; Mercadé-Melé, P.; Moreno-Sáez, R.; Muñoz, A.; Palomo-Hierro, S.; Torres, A. Using Peer Review for Student Performance Enhancement: Experiences in a Multidisciplinary Higher Education Setting. Educ. Sci. 2021, 11, 71. [CrossRef]

25. Södervik, I.; Nousiainen, M.; Koponen, I.T. First-Year Life Science Students' Understanding of the Role of Plants in the EcosystemA Concept Network Analysis. Educ. Sci. 2021, 11, 369. [CrossRef]

26. Suleman, F.; Videira, P.; Araújo, E. Higher Education and Employability Skills: Barriers and Facilitators of Employer Engagement at Local Level. Educ. Sci. 2021, 11, 51. [CrossRef] 